\title{
Forecast of the Economic- Financial Performance Based on Diagnostic Analysis
}

\author{
Daniela Cristina Solomon, University "Vasile Alecsandri" of Bacau, Romania \\ Simona Elena Dragomirescu, University "Vasile Alecsandri” of Bacau, Romania
}

\begin{abstract}
To ensure efficient financial management is necessary to achieve the forecast of economic and financial performance on the basis of diagnostic analysis, approach most often developed starting from the prediction of turnover and also necessary for shaping an organization's prospects. In financial management, the turnover's increasing is considered an objective in itself, being interpreted as generating increased market share, profit. Sales condition therefore the entire activity of a company, their variation being considered the main risk factor of enterprise's economic and financial performance and the staring point in their forecast.
\end{abstract}

\section{Keywords}

performance, economic-financial indicators, diagnostic analysis, forecasting

JEL code: D81, G17, M49, P47

\section{Data analysis of profit and loss account}

The first step towards financial forecast consists in the analysis of data from profit and loss account, in order to identify the existent correlations between the evolution of the main performance indicators and changes in turnover.

Financial forecast may be realized on the basis of three methods, namely": the "percentage of turnover" method, "period rotation" or "rotation speed" method and regression method.

To achieve economic-financial forecasting performance of two companies the method "percentage from turnover" will be applied based on the previous data, without taking into account any changes that may occur in the structure of enterprise's activity.

Sales condition the entire activity of the enterprise and their variation is considered the main risk factor on the enterprise financial performance. In determining the sales forecast there should be taken into account such factors as ${ }^{2}$ : prices level, competition, suppliers' conditions, the marketing mix. Marketing tools that provide the achieving of the objectives are grouped into 4 categories: product (range, quality, features, packaging, services), price (discounts, pay period), promotion (advertising, sales force, public relations) and placement (channels, stocks, transportation).

Although only part of the structural elements of the profit and loss are dependent (varies proportionally) as against the sales volume (such as operating income, operating costs),

\footnotetext{
${ }^{1}$ Dragotă, V., Dragotă, M., Obreja, L. Tatu, L., Ciobanu, A., Racşa, A. (2005), Abordări practice în finanțele firmei (Practical Approaches in finance company), IRECSON Publishing House, Bucharest, pp 69-89.

${ }_{2}^{2}$ Albu, N., Albu, C. (2003), Instrumente de management al performanței, vol. II Control de gestiune (Performance Management Tools, vol II, Accountancy Management), Economic Publishing House, Bucharest, p. 40.
} 
others are independent, respectively their values are determined by other factors (for instance: extraordinary income and expenses - are not influenced by the workload, but by the occurrence of unforeseen events, the extraordinary ones), the application of the method starts from the principle of linearity of the evolution of all structures in the profit and loss account in relation to turnover.

\section{Forecasting turnover}

Another step, extremely important, is forecasting turnover and can be realized on one of the following methods: using historical data, or using sustainable growth rate.

In specific literature ${ }^{3}$ we find other methods of sales volume planning, such as: the causal approach; the non-causal approach, the direct method, the indirect method; the court methods, statistical methods (trend analysis, correlation analysis, targeted approach, industry analysis method, production line analysis, final user analysis). All methods have advantages and drawbacks. Evidence shows that most large enterprises use the combination of these methods.

\section{“Using historical data” Method}

Method "using historical data" implies the use of turnovers from the two companies registered during 2004-2008 period to determine the expected turnover (for 2009). Method of aggregation of data from the past is made by using the average rate of growth. In this case, the expected growth rate in turnover is the average (simple or weighted arithmetic) of the growth rates recorded in the past:

- $\quad$ simple arithmetic mean is:

$$
\bar{g}=\frac{\sum_{t=1}^{T} g_{t}}{T}=\frac{\sum_{t=1}^{T} \frac{C A_{t}-C A_{t-1}}{C A_{t-1}}}{T}
$$

where: $\bar{g}=$ the average growth rate of turnover;

$\mathrm{g}_{\mathrm{t}}=$ growth rate of turnover in year $\mathrm{t}, \mathrm{t}=1,2,3,4$, or 5 ;

$\mathrm{T}=$ number of periods in our case $\mathrm{T}=5$.

- weighted arithmetic mean is:

$$
\bar{g}=\frac{\sum_{t=1}^{T} g_{t} \cdot t}{\sum_{t=1}^{T} t}=\frac{\sum_{t=1}^{T}\left(\frac{C A_{t}-C A_{t-1}}{C A_{t-1}}\right) \cdot t}{\sum_{t=1}^{T} t}
$$

Depending on the average rate (simple or weighted arithmetic) of growth in turnover, the predicted turnover for next period is determined:

$$
C A_{\text {prek }(T+1)}=C A_{T} \cdot(1+\bar{g})
$$

\section{FORECAST Function}

\footnotetext{
${ }^{3}$ Rachlin, R. (2007) Sistemul complet de bugete ale firmei. Ghid practic şi formulare de lucru (The complete business budgets. Practical Guide and forms of work), edition II (trad.: Manea FC, trans. and adjust.: Paunescu, M., ed. coord. Christmas E), Bucharest, BMT Publishing House, pp 103-106.
} 
The predicted turnover value can be obtained through application of FORECAST function which is available through table calculation program Microsoft Excel. In calculation of this function the volume of turnover in the period 2004-2008 and development price index (inflation rate) were taken into account.

Function syntax is as follows:

$$
\text { FORECAST(x,known_y's,known_x's) }
$$

where: $x=$ the expected price index value; $x=5,60 \%$;

known_y's = dependent variables matrix, namely the turnover values for 2004-2008 period;

known_ $x^{\prime} s=$ independent variables matrix, namely price index values for 20042008 period.

FORECAST equation is: $\mathrm{y}=\mathrm{a}+\mathrm{bx}$,

where: $a=\bar{y}-b \cdot \bar{x} ; \quad b=\frac{\sum(x-\bar{x}) \cdot(y-\bar{y})}{\sum(x-\bar{x})^{2}}$

In the case of the two companies, the forecast turnover calculation through the methodology described above is presented in Table 1.

Table 1 Estimation of turnover

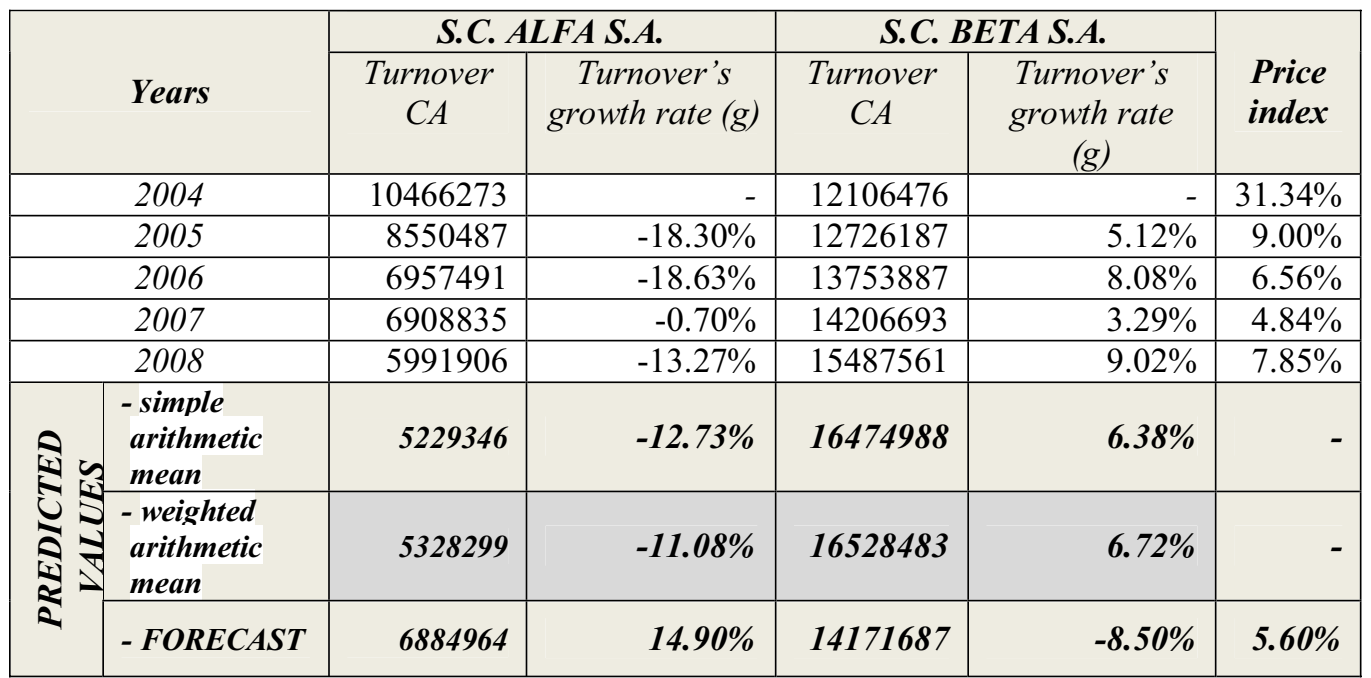

\section{Forecast of indicators for assessing economic-financial performance.}

The average percentage held by each indicator in the turnover previously projected is applied (determined by the weighted arithmetic mean) on the expected value of turnover.

Calculation of expected values is presented in Table 2 and graphical representation of projected economic and financial performance is suggestively presented in Figure 1 for SC ALFA S.A. and figure 2 for S.C. BETA S.A. 
Table 2 Predicting economic - financial performance

\begin{tabular}{|lcrrrrr|}
\hline Explication & CA & Rexp & Rfin & \multicolumn{1}{c|}{ Rert } & \multicolumn{1}{c|}{ Rbr } & \multicolumn{1}{c|}{ Rnet } \\
\hline \multicolumn{1}{|l}{ Average percent from $\boldsymbol{C A}$} & & & & & \\
\hline ALFA & - & $6.94 \%$ & $1.05 \%$ & $7.99 \%$ & $7.99 \%$ & $6.54 \%$ \\
\hline BETA & - & $37.99 \%$ & $4.86 \%$ & $42.85 \%$ & $42.85 \%$ & $35.64 \%$ \\
\hline Value predicted through extrapolation & & & & \\
\hline ALFA & 5328299 & 369766 & 55956 & 425722 & 425722 & 348247 \\
BETA & 16528483 & 6279708 & 802497 & 7082205 & 7082205 & 5890165 \\
\hline Value predicted FORECAST & & & & & \\
\hline ALFA & 6884964 & 477793 & 72304 & 550097 & 550097 & 449987 \\
BETA & 14171687 & 5384285 & 688069 & 6072354 & 6072354 & 5050287 \\
\hline
\end{tabular}

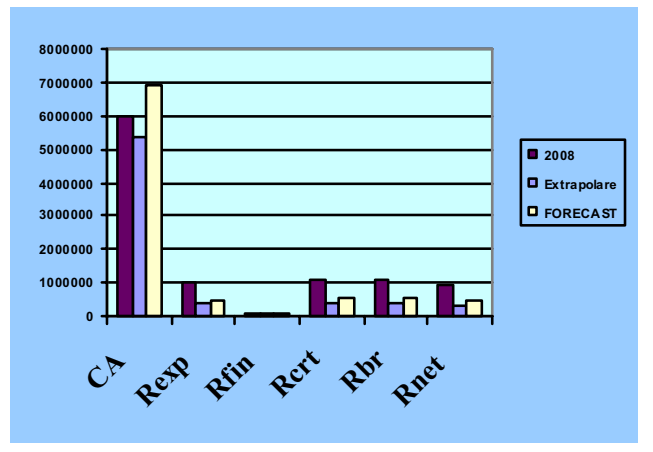

Figure 1 Forecast of economic and financial performance of SC ALFA S.A.

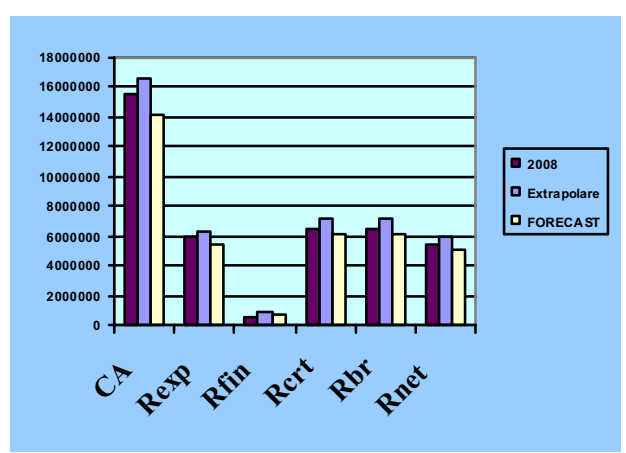

Figure 2 Forecast of economic and financial performance of SC BETA S.A.

We can observe that the estimated value of turnover for SC ALFA S.A. recorded the value of 5.328.299 lei through extrapolation and respectively 6.884.964 lei using FORECAST function. Between two values, we consider that lower value - that obtained by extrapolation, is closer to reality. Forecasting through FORECAST function is too optimistic and has led to increased turnover from the level projected in 2008, given current economic uncertainty, but still fall below the turnover achieved in 2004-2007.

In the case of S.C. BETA S.A. the value of the projected turnover obtained by extrapolation would register an increase of $6.72 \%$, while using the FORECAST function it would decrease by $8.50 \%$, and in this situation we choose the extrapolation alternative because the firm proves sustainable economic performance, inflation rate tends to stabilize, and the objective of increasing turnover is realistic for the company.

We can observe that turnover forecast in growth determines the estimation of favorable economic and financial performances and vice versa.

Regarding the application of a sales forecast methods and interpretation of the obtained results, there are some limitations:

$\square$ first, correlation does not mean causation, so the real cause of the link between economic variables may be a variable not taken into account yet;

$\square$ secondly, the identification of the factor determinant in sales estimation is not easily achieved; there must be added that sales are actually under the influence of several factors, and also can lead to errors of interpretation because of the relationship between some variables logically unrelated; some correlations between variables may simply be due to chance and not economic logic; 
$\square$ the use of historical data to estimate future growth in turnover is useful, but is not sufficient information; empirical analysis shows that it is unlikely that firms that have registered faster growth in certain periods to continue the same pace and in subsequent periods.

\section{Conclusions}

In conclusion, we consider that a correct forecast of sales is vital to long-term enterprise success. Relevance of previously recorded data for forecasting future data depends on the stability of the company's economic activity and the environment in which it acts, stability which is influenced by the following factors ${ }^{4}$ : volatility of growth rates; company's size: because growth is measured as a percentage, firm's size should be taken into account - the increased size of the firm makes more difficult to maintain high growth rates; economic cycle: if the company's activity is influenced by economic change is essential when choosing data analysis; estimating the growth rate during several economic cycles is required; structural changes: the growth rates recorded are the result of policy mix adopted by the firm: investment policy, financing policy, dividend policy; given that the company amended one of these policy information to that moment become irrelevant for predicting future developments.

\section{Bibliography}

1. Albu, N., Albu, C. (2003), Instrumente de management al performantei, vol. II Control de gestiune (Performance Management Tools, vol II, Accountancy Management), Economic Publishing House, Bucharest.

2. Dragotă, V, Ciobanu, A., Oreja, L. Dragotă, M. (2003), Management financiar (Financial Management), Economic Publishing House, Bucharest.

3. Dragotă, V., Dragotă, M., Obreja, L. Tatu, L., Ciobanu, A., Racşa, A. (2005), Abordări practice în finanțele firmei (Practical Approaches in Finance Company), IRECSON Publishing House, Bucharest. 4. Obreja, L. (2006), Investiții (Investment), Digital Library, Academy of Economic Studies, Bucharest. 5. Rachlin, R. (2007), Sistemul complet de bugete ale firmei. Ghid practic şi formulare de lucru (The complete business budgets. Practical Guide and forms of work), $2^{\text {nd }}$ edition (trans.: Manea FC, trans. and adjustment: Paunescu, M., ed. coord. Christmas E), BMT Publishing House, Bucharest.

4 Dragotă, V, Ciobanu, A., Oreja, L. Dragotă, M. (2003), Management financiar (Financial Management), Economic Publishing House, Bucharest, p. 81; Obreja, L. (2006), Investiții (Investment), Digital Library, Academy Economic Studies, Bucharest, p. 57. 